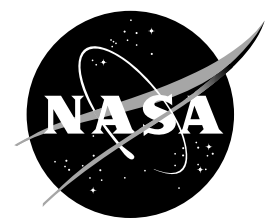

\title{
Update on International Space Station Nickel-Hydrogen Battery On-Orbit Performance
}

Fred Cohen

The Boeing Company, Canoga Park, California

Penni Dalton

Glenn Research Center, Cleveland, Ohio 
Since its founding, NASA has been dedicated to the advancement of aeronautics and space science. The NASA Scientific and Technical Information (STI) Program Office plays a key part in helping NASA maintain this important role.

The NASA STI Program Office is operated by Langley Research Center, the Lead Center for NASA's scientific and technical information. The NASA STI Program Office provides access to the NASA STI Database, the largest collection of aeronautical and space science STI in the world. The Program Office is also NASA's institutional mechanism for disseminating the results of its research and development activities. These results are published by NASA in the NASA STI Report Series, which includes the following report types:

- $\quad$ TECHNICAL PUBLICATION. Reports of completed research or a major significant phase of research that present the results of NASA programs and include extensive data or theoretical analysis. Includes compilations of significant scientific and technical data and information deemed to be of continuing reference value. NASA's counterpart of peerreviewed formal professional papers but has less stringent limitations on manuscript length and extent of graphic presentations.

- TECHNICAL MEMORANDUM. Scientific and technical findings that are preliminary or of specialized interest, e.g., quick release reports, working papers, and bibliographies that contain minimal annotation. Does not contain extensive analysis.

- CONTRACTOR REPORT. Scientific and technical findings by NASA-sponsored contractors and grantees.
- CONFERENCE PUBLICATION. Collected papers from scientific and technical conferences, symposia, seminars, or other meetings sponsored or cosponsored by NASA.

- SPECIAL PUBLICATION. Scientific, technical, or historical information from NASA programs, projects, and missions, often concerned with subjects having substantial public interest.

- TECHNICAL TRANSLATION. Englishlanguage translations of foreign scientific and technical material pertinent to NASA's mission.

Specialized services that complement the STI Program Office's diverse offerings include creating custom thesauri, building customized databases, organizing and publishing research results ... even providing videos.

For more information about the NASA STI Program Office, see the following:

- Access the NASA STI Program Home Page at http://www.sti.nasa.gov

- E-mail your question via the Internet to help@sti.nasa.gov

- Fax your question to the NASA Access Help Desk at 301-621-0134

- Telephone the NASA Access Help Desk at 301-621-0390

- Write to:

NASA Access Help Desk

NASA Center for AeroSpace Information 7121 Standard Drive

Hanover, MD 21076 
NASA/TM-2003-212542

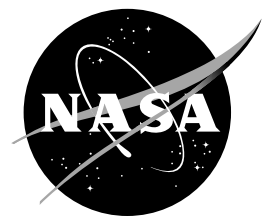

\section{Update on International Space Station Nickel-Hydrogen Battery On-Orbit Performance}

Fred Cohen

The Boeing Company, Canoga Park, California

Penni Dalton

Glenn Research Center, Cleveland, Ohio

Prepared for the

First International Energy Conversion Engineering Conference cosponsored by the American Institute of Aeronautics and Astronautics (AIAA), the American Society of Mechanical Engineers (ASME), and the Institute of Electrical and Electronics Engineers (IEEE)

Portsmouth, Virginia, August 17-21, 2003

National Aeronautics and

Space Administration

Glenn Research Center 
Available from

NASA Center for Aerospace Information 7121 Standard Drive

Hanover, MD 21076
National Technical Information Service 5285 Port Royal Road Springfield, VA 22100

Available electronically at http:/ /gltrs.grc.nasa.gov 


\title{
UPDATE ON INTERNATIONAL SPACE STATION NICKEL-HYDROGEN BATTERY ON-ORBIT PERFORMANCE
}

\author{
Fred Cohen \\ The Boeing Company \\ Rocketdyne Propulsion \& Power \\ Canoga Park, California 91309 \\ Penni Dalton \\ National Aeronautics and Space Administration \\ Glenn Research Center \\ Cleveland, Ohio 44135
}

\begin{abstract}
International Space Station (ISS) Electric Power System (EPS) utilizes Nickel-Hydrogen $\left(\mathrm{Ni}-\mathrm{H}_{2}\right)$ batteries as part of its power system to store electrical energy. The batteries are charged during insolation and discharged during eclipse. The batteries are designed to operate at a 35\% depth of discharge (DOD) maximum during normal operation.
\end{abstract}

Thirty-eight individual pressure vessel (IPV) $\mathrm{Ni}-\mathrm{H}_{2}$ battery cells are series-connected and packaged in an Orbital Replacement Unit (ORU). Two ORUs are series-connected utilizing a total of 76 cells, to form one battery. The ISS is the first application for low earth orbit (LEO) cycling of this quantity of seriesconnected cells.

The P6 (Port) Integrated Equipment Assembly (IEA) containing the initial ISS high-power components was successfully launched on November 30, 2000. The IEA contains 12 Battery Subassembly ORUs (6 batteries) that provide station power during eclipse periods. This paper will discuss the battery performance data after two and a half years of cycling.

\section{INTRODUCTION}

At Assembly Complete (AC), the ISS Electric Power System (EPS) will be powered by 24 batteries during eclipse and extended operation periods. The batteries are evenly divided between four Integrated Equipment Assemblies (IEA), as part of the four photovoltaic modules (PVM). The fourth and final PVM will complete the EPS and is scheduled for a launch not earlier than June 2004. The battery ORU (see Fig. 1) is designed to operate for 6.5 years, with a mean-timebetween-failure (MTBF) of 5 years, when run in the reference design 35\% Depth of Discharge (DOD) low earth orbit (LEO) regime. Typical expected discharge currents can range from $<25 \mathrm{Amps}$ in a low-demand orbit to as high as $\sim 75$ Amps to meet short peaking load requirements at a battery operating voltage range of 76 to $123 \mathrm{Vdc}$. The ORUs are individually fused to protect the ISS EPS from fault propagation that could result from a cell-to-EPS ground short event. Primary charge control is accomplished by a pressure temperature algorithm, which incorporates acceptance test data in order to initialize basic reference parameters.

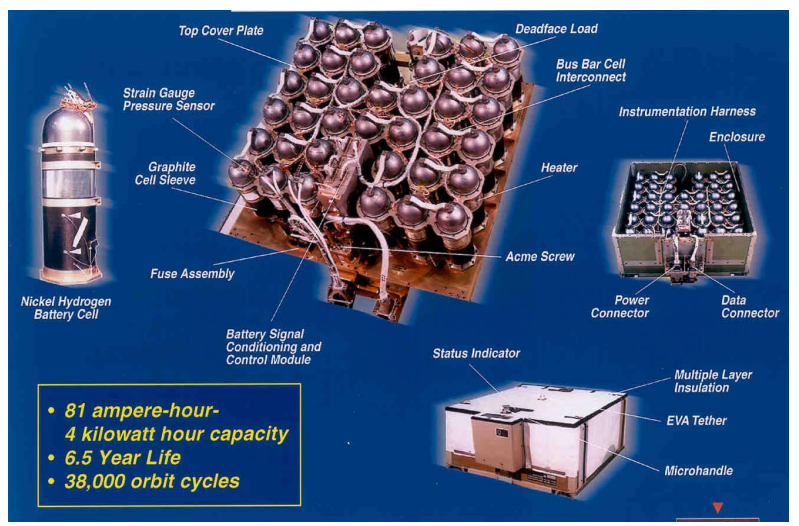

FIGURE 1. ISS BATTERY SUBASSEMBLY ORU

The ISS power system is the first on-orbit use of such a large quantity of series-connected individual pressure vessel (IPV) $\mathrm{Ni}-\mathrm{H}_{2}$ battery cells, in an ORU/Battery (38/76 cells) configuration.

\section{ORU DESIGN CONSIDERATIONS}

The original ISS battery design effort began in 1988, and identified the need for a long-life, highperformance, high-reliability battery. Therefore, stateof-the-art $\mathrm{Ni}_{2} \mathrm{H}_{2}$ IPV chemistry was chosen. The battery ORU was designed to meet the following requirements: 
- 6.5-year design life

- 81-Amp-hr nameplate capacity to limit the maximum reference DOD to less than $35 \%$

- Contingency orbit capability consisting of one additional orbit at reduced power after a $35 \%$ DOD without recharge

- 5-year MTBF

- Easy on-orbit replacement, utilizing the robotic arm

The cells selected for use in the Battery ORUs are manufactured by Eagle Picher Industries. The cells are RNH-81-5 EPI IPV $\mathrm{NiH}_{2}$, and utilize a back-to-back plate configuration. They are activated with a $31 \%$ aqueous solution of potassium hydroxide $(\mathrm{KOH})$ electrolyte. The ORUs are assembled and acceptance tested by Space Systems/Loral.

\section{ISS BATTERY CONFIGURATION}

The Battery Subassembly ORU, as designed and built, is pictured in Figs. 2 and 3.

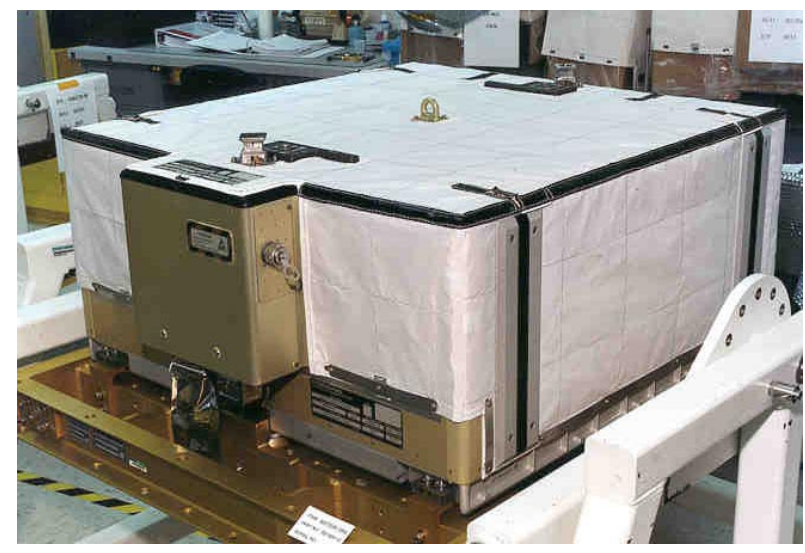

\section{FIGURE 2. ISS BATTERY SUBASSEMBLY ORU} WITH MLI BLANKET

$\mathrm{NiH}_{2}$ cells for the current 12 ISS Battery ORUs on the P6 IEA were manufactured and activated 3.6 to 4.4 years prior the November 30, 2000 launch date. The flight ORUs were used for IEA systems ground testing and final checkout, but were stored open-circuit, discharged, and at $-10{ }^{\circ} \mathrm{C}$ when they were not in use

Twelve Battery ORUs were integrated onto the P6 IEA in July 2000 at the Kennedy Space Center (KSC). These 12 ORUs comprise six separate batteries, with three batteries on each of two power channels. For the
P6 IEA, these power channels are designated as 2B and 4B. During insolation, power is supplied to the main bus by solar arrays that meet both the demands of user loads and battery recharge. The batteries interface through a Battery Charge/Discharge Unit (BCDU) and provide the power to the source bus for the ISS during eclipse periods.

Each ORU is individually fused for fault propagation protection of the EPS in the event of a cell short. The 120 -amp fuse block consists of two parallel fuse strings, one 60 ampere string on each power cable. The fuses are constructed using high voltage, high reliability space rated components. Each battery ORU also contains a letdown resistor assembly that can be connected across the power terminals to provide the capability for completely discharging the hardware at the ORU level.

The battery ORU contains a Battery Signal Conditioning and Control Module (BSCCM). The BSCCM provides conditioned battery monitoring signals from the ORU to the Local Data Interface (LDI) located within the BCDU. Available data includes 38 cell voltages, four pressure (strain gauge) readings, six cell and three baseplate temperatures. This data is provided as an analog multiplexed voltage. A separate signal provides ORU total voltage output. The BSCCM also accepts and executes commands from the BCDU/LDI to control ORU cell heater and resistor letdown functions.

For battery charging, the BCDU conditions power from the $160 \mathrm{~V}$ source bus and charges the battery at predetermined currents that are calculated based on State of Charge (SOC). The charging algorithm, based on a temperature and pressure SOC calculation, was described in a previous paper ${ }^{1}$. During periods of eclipse, the BCDU extracts power from the battery, conditions this power, and supplies power to the source bus.

The batteries are actively cooled using the ISS Thermal Control System (TCS). The battery cells are assembled in an ORU box, using a unique finned radiant heat exchanger baseplate. The ORU is then mounted on the IEA using ACME screws and mated to the TCS. The TCS was designed to maintain the Battery ORUs at a nominal operating temperature range of $5 \pm 5^{\circ} \mathrm{C}(41 \pm$ $9^{\circ} \mathrm{F}$ ) with minimum heater operation when run at a $35 \%$ DOD LEO regime. 


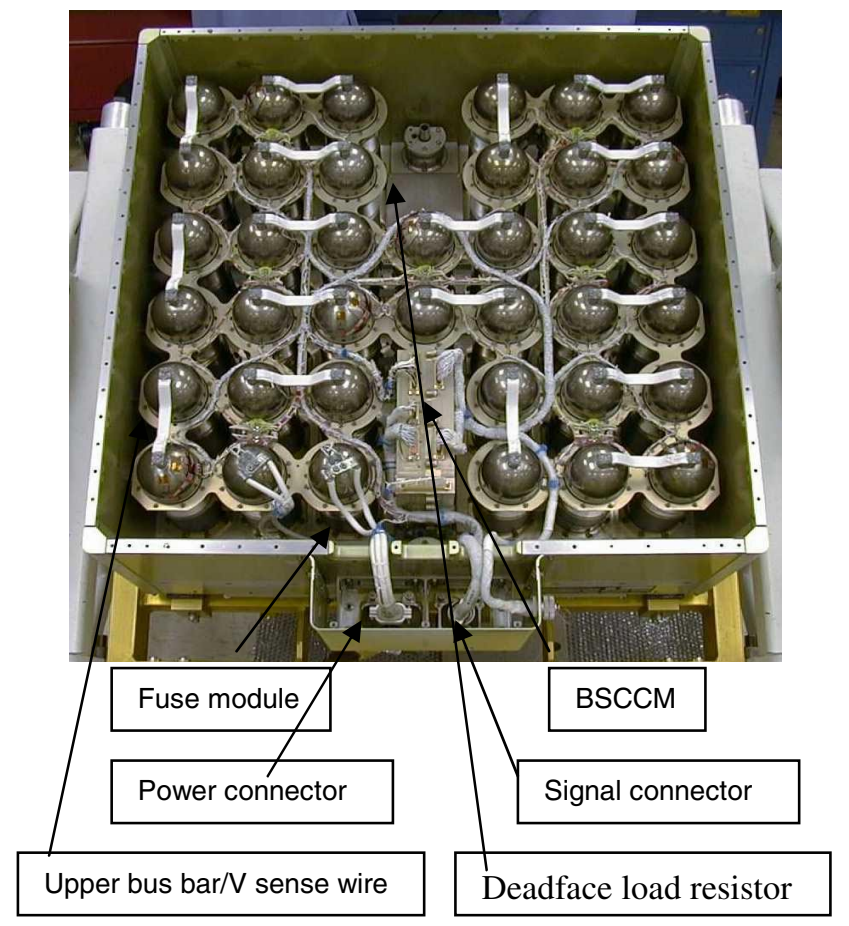

FIGURE 3. ISS FLIGHT MODEL BATTERY SUBASSEMBLY ORU WITH COVER REMOVED

\section{ISS ON-ORBIT OPERATION}

The ISS main power system charge algorithm has preset parameters. Maximum charge rate is determined and set based on the on-orbit operation need. Currently, a 50-Amp maximum charge rate set point is employed due to operating scenarios that feather arrays to save fuel and/or reduce the possibility of charge build-up on the ISS structure during EVA activity. As such, it is necessary to replenish the battery energy used during eclipse as quickly as possible when it is available from the solar arrays. The taper charge profile is pre-programmed in a look-up table with the following parameters:

\begin{tabular}{|c|l|l|l|l|l|l|l|l|l|}
\hline SOC\% & 20 & 85 & 90 & 94 & 96 & 98 & 1.00 & 1.01 & $>1.05$ \\
\hline $\begin{array}{c}\text { Chg Rate } \\
\text { (Amps) }\end{array}$ & 50 & 50 & 50 & 50 & 40 & 27 & 10 & 5 & 1 \\
\hline
\end{tabular}

TABLE 1. CHARGE PROFILE LOOK-UP

The charge profile look-up table (above) is on-orbit programmable and can be revised at any time via a software upload. Changes to the table allow for flexibility, enabling optimal charge rates for changing operational scenarios, as well as for compensation of changing battery performance characteristics caused by aging.

\section{ISS ON-ORBIT DATA}

The ISS on-orbit data is telemetered to the ground, and is available real time through data screens on consoles located in the Mission Engineering Room (MER) at Johnson Space Center (JSC). Stored, long-term data can be accessed from the Orbiter Data Reduction Complex (ODRC). The on-orbit start-up procedures and the battery initial performance were reported previously. ${ }^{1}$

\section{Representative Data}

Current on-orbit data is shown following the text in Figs 9 through 18. This data is for flight day April 4, 2003 for channel 2B and April12, 2003 for channel 4B. As of these dates, the batteries had completed approximately 13,632 and 13,760 LEO cycles respectively. The data depicts one battery for each channel. Spaces in the data are caused by data drop-out and are not intentional omissions. The data clearly shows that the batteries are performing within their design specifications over the operational range.

For the referenced data:

- Battery voltage (76 cells) 95 to $117 \mathrm{Vdc}$ (Figures 9 and 10)

- Maximum charge rate $50 \mathrm{Amps}$ (note that due to ISS EPS conventions, charging current is shown as negative)

- Cell voltages $\sim 1.22$ to $\sim 1.56 \mathrm{Vdc}$, with little divergence (Figures 11 and 12)

- Average ORU temperature range $\sim 0.0$ to $5.5^{\circ} \mathrm{C}$ (Figures 13 and 14)

- Average battery pressure $\sim 550$ to $\sim 750$ psi (Note 4B2 delta pressures between ORUs) (Figures 15 and 16)

- Average SOC $\sim 86 \%$ to $~ 111 \%$ (Note: Batteries on both channels are operating well below DOD design point, with $4 \mathrm{~B}$ running at a lighter load than 2B) (Figures 17 and 18)

\section{Cycle Life Predictions}

The cycling regime has been fairly benign over the last 30 months, averaging well below the design reference point of 35\% DOD. Figure 4 is a plot of the average actual DODs and have ranged, to date, from a low of $10 \%$ to a high of $35 \%$. Future DOD estimates, based on power level projections, range from $16 \%$ to $38 \%$ DOD, with an average of about $26 \% \mathrm{DOD}^{2}$. Using the Space Systems Loral performance-based battery design life model, figure 5, these predicted DODs, and assuming a moderate amp-hour recharge fraction of less than 1.05, the P6 battery life is expected to meet or exceed the ISS 6.5 year life requirement. 


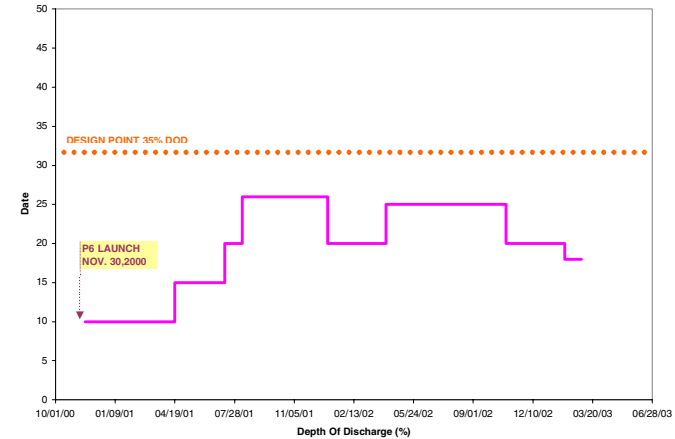

FIGURE 4. AVERAGE PER-PERIOD ON-ORBIT DOD FOR PG BATTERIES

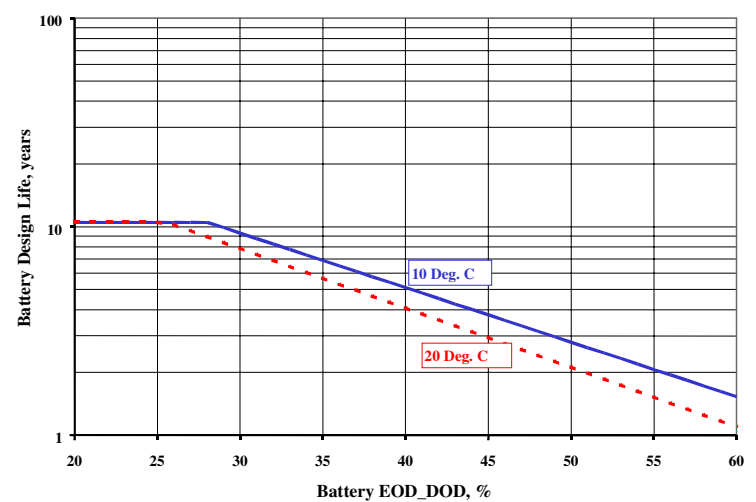

FIGURE 5. BATTERY DESIGN LIFE MODEL

An independent assessment of the ISS battery operation and life was performed by the Aerospace Corporation for the ISS program early this year. ${ }^{3}$ Data from ISS sponsored ground tests and from the orbiting station was analyzed and incorporated into a battery cell wearout model. The model was developed using DOD, operating temperature, calendar life, and the peak recharge voltage and the ampere-hours of overcharge. For the ISS batteries, the model indicates that most of the wear and stress is due to the amount of overcharge that they receive during on-orbit operations. Projections for life are about 6.5 years using the present charge regime and a continuing average 16\% DOD. The analysis estimates that an early reduction in the amount of overcharge will result in an additional 3 years of life (figure 6). This was a prediction of approximately 9 years of on-orbit operation for the ISS batteries if overcharge reduction was implemented by February 2003. This overcharge reduction has not been implemented as June 2003.

\section{Effect of Initial Wear (prior to launch)}

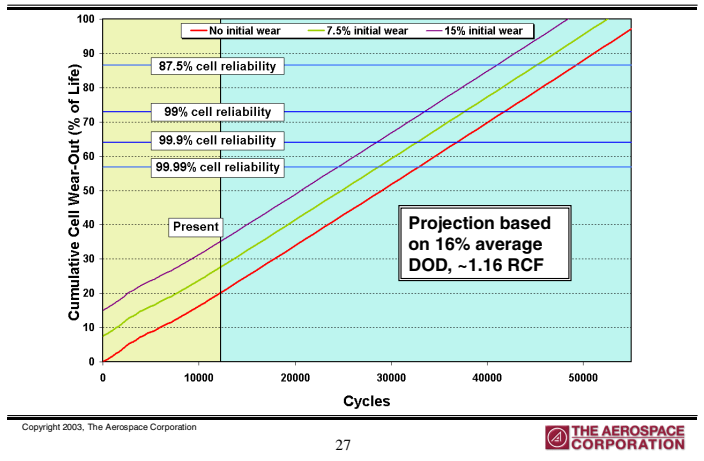

FIGURE 6. EFFECT OF INITIAL WEAR ON LIFE

The ISS Program is currently evaluating the implementation of an improved charge profile, one that would reduce overcharge as well as peak charge voltages. In addition, we have recommended that the Program consider the use of routine (annual or biannual) reconditioning of the batteries, both for maintaining cell balance, as well as to provide data for the update of and optimization of battery capacity and SOC calculations.

\section{Battery 4B2 Pressure Delta}

Note in Figure 16 that battery 4B2 has exhibited a pressure divergence between the two ORUs. The divergence has grown with cycling. Battery 4B2 contains a mismatched set of ORUs. In the Battery 4B2, ORU 4B2A had more ground testing than ORU 4B2B. The ORUs are charged as a pair, but the SOC, and thus the charge rates, are based on the average of the SOC for the two ORUs. This led to an undercharge of $4 \mathrm{~B} 2 \mathrm{~B}$, and a slight overcharge of $4 \mathrm{~B} 2 \mathrm{~A}$.

The first reinitialization procedure for reducing the Battery 4B2 pressure delta was performed in February, 2002. The battery was discharged during eclipse, with no charge during insolation periods, until the first cell reached $0.7 \mathrm{~V}$. The individual ORU drain resistors were then engaged. Each ORU was discharged through the resistor until the first cell reached $0.1 \mathrm{~V}$. At the completion of this procedure, the pressure difference had dropped from a high of about 160 psi to 42 psi. The capacity of 4B2B was estimated to be 56 Ah and the capacity of 4B2A was around $76 \mathrm{Ah}$. The total useable battery capacity will be limited by the 4B2B capacity of $56 \mathrm{Ah}$, however, this capacity is sufficient to 
meet ISS requirements. A more detailed description of the initial reinitialization was previously published. ${ }^{4}$

Following the reinitialization, the Battery 4B2 pressure delta continued to rise. Three additional attempts to equalize the pressures and capacities of these two ORUs were performed throughout the year, figure 7 . The first drain resistor procedure was performed in May, 2002. The drain resistor on ORU 4B2A was closed 5-10 minutes prior to the start of the eclipse period and opened 5-10 minutes into the start of insolation period, for a maximum duration of 45 minutes every orbit. The pressure delta did decrease for the first 4 orbits and then leveled. The procedure was terminated. Analysis of the data indicated that during this time, the eclipse periods were very short, resulting in a prolonged trickle charge to the battery. This reduced the effectiveness of the procedure.

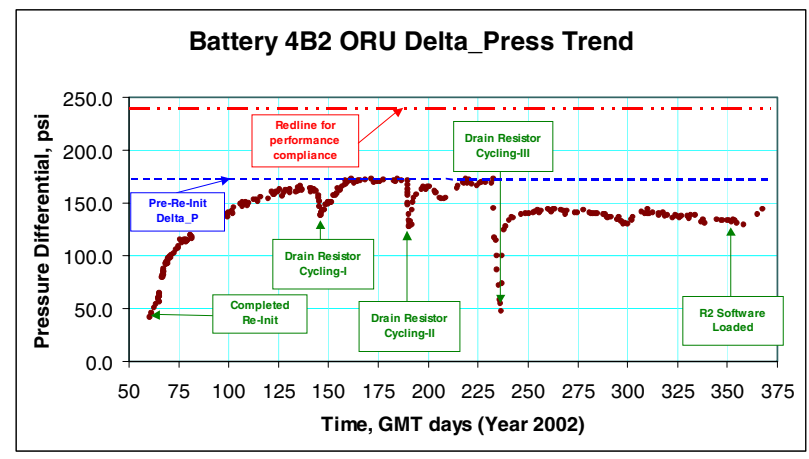

\section{FIGURE 7. REDUCTION OF BATTERY 4B2 PRESSURE DELTA}

The drain resistor procedure was tried again in July, 2002. The pressure delta did decrease for the first eight hour of the procedure, but then leveled. Analysis of the data again revealed that the ISS was in a period of extremely short eclipses and extended trickle charge during insolation.

The third drain resistor cycling procedure was performed in August, 2002. Lessons learned from the first and second drain resistor cycling were incorporated into the third procedure. For this procedure, trickle charge was minimized by shunting the array. The ORU 4B2A drain resistor was engaged for 3 full orbits, followed by one orbit with the drain resistor open. The procedure was then modified to have the drain resistor continuously closed. At the completion of the procedure (a delta pressure of less than $50 \mathrm{psi}$ ), the temperature was raised on Battery
ORU 4B2A by approximately $3^{\circ} \mathrm{C}$. The pressure delta has now stabilized between 135-145 psi, well below the estimated redline delta pressure, figure 8 . The dashed line is the delta pressure estimate of the point at which the battery will no longer have enough capacity to meet its on-orbit requirements.

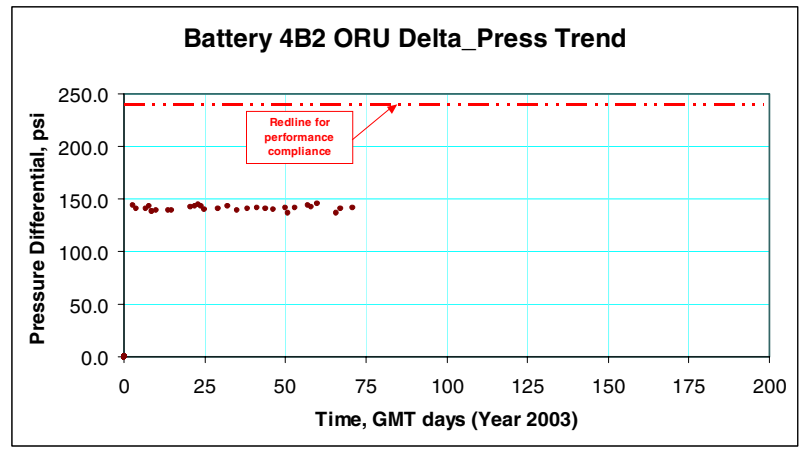

\section{FIGURE 8. BATTERY 4B2 PRESSURE TRENDING, POST-DRAIN CYCLING}

\section{FUTURE WORK}

All 36 ORUs necessary for the completion of the ISS EPS have been delivered to Kennedy Space Center and are currently being integrated into the three IEAs. Due to launch delays, special on-IEA, room ambient storage methods have been implemented. The current method was developed, taking into account technical, cost, and schedule impacts. Data will be analyzed during the storage period. On-orbit data will continue to be evaluated. Recommendations for optimization of both ground storage and on-orbit battery operation will be made as the program progresses. An evaluation for the incorporation of advanced technology batteries for the year 2010 is in process.

\section{CONCLUSIONS}

The International Space Station Electric Power System is successfully maintaining power for all on-board loads. Power during the eclipse is currently supplied by six $\mathrm{NiH}_{2}$ batteries (three batteries per channel). The batteries are designed for a LEO 35\% DOD cycle, however, due to the low power demands at this point in the ISS assembly phase, they have been operating between 10 and 35\% DOD. The batteries are operating nominally and have exceeded all ISS requirements. The power system will be complete following the tentatively scheduled launch of the second, third, and fourth PVMs in October of 2003, and March and June of 2004. 


\section{REFERENCES}

1) Cohen, F., and Dalton, P. J., "International Space Station Nickel-Hydrogen Battery Start-up and Initial Performance," Proceedings of the $36^{\text {th }}$ Intersociety Energy Conversion Engineering Conference, Savannah, GA., August 2001.

2) Gonzalez, F., "ISS Integrated Energy Balance Analysis - Preliminary DAC9, Revision F," Houston, TX, January 2001.

3) Zimmerman, A. H., "Independent Analysis of the Battery Reconfiguration Process of the ISS," Aerospace Report No. ATR-2003(7828)-2, February 2003.

4) Hajela, G, and Cohen, F, "Battery Re-Initialization on the Photovoltaic Module of the International Space Station," Proceedings of the $36^{\text {th }}$ Intersociety Energy Conversion Engineering Conference, Savannah, GA., August 2001. 


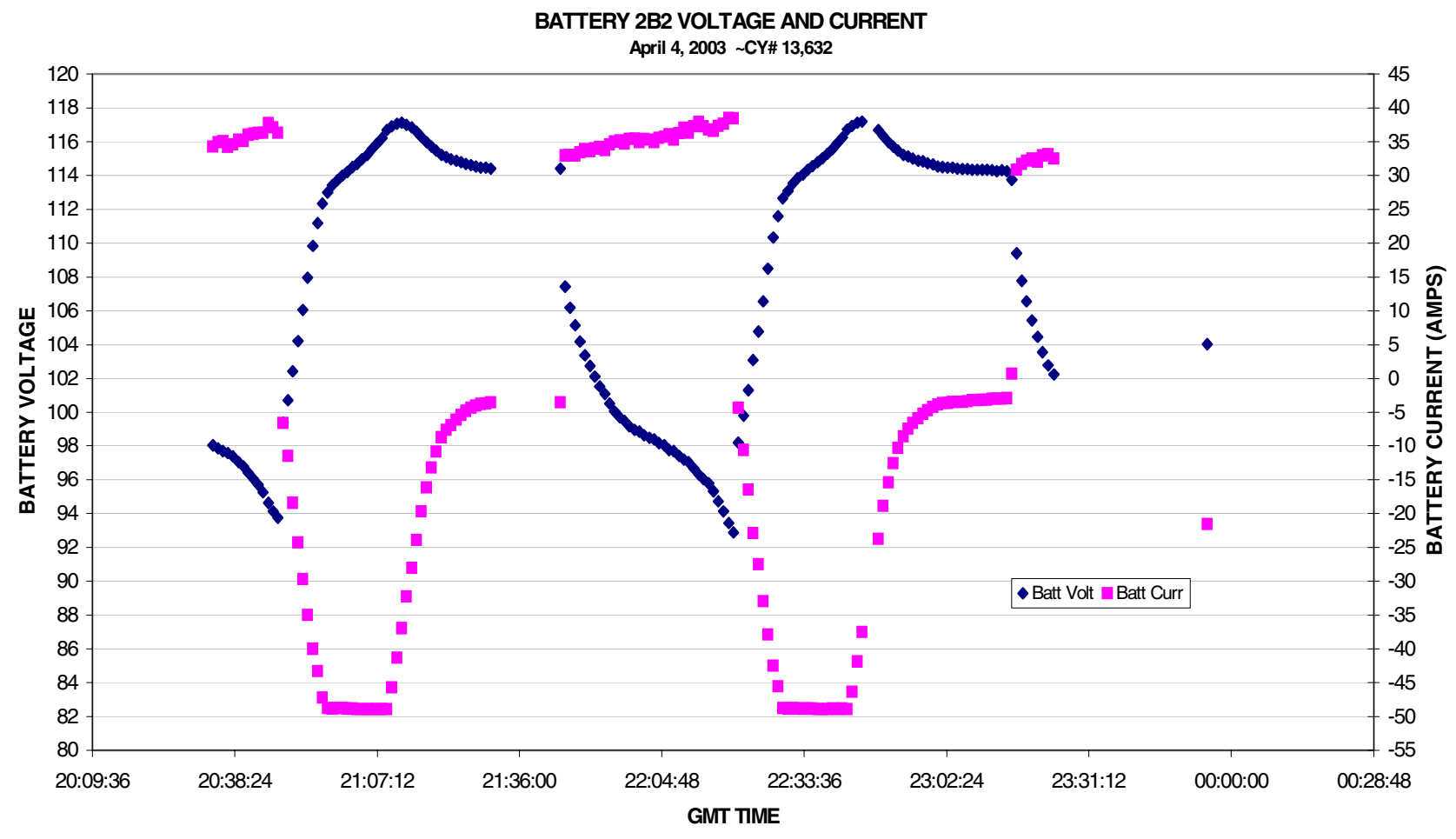

FIGURE 9. BATTERY 2B2 VOLTAGE AND CURRENT

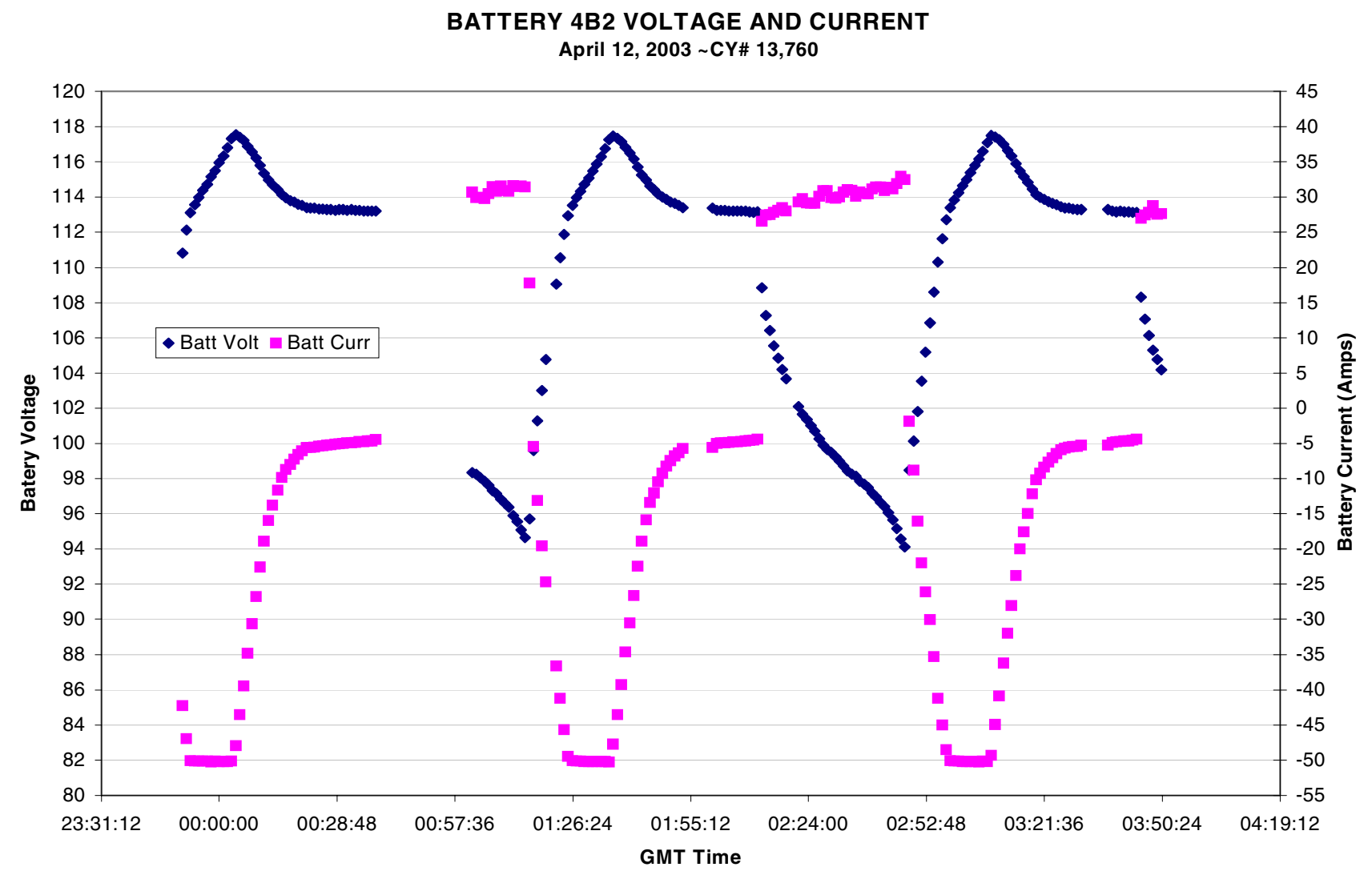

FIGURE 10. BATTERY 4B2 VOLTAGE AND CURRENT 
BATTERY 2B2 CELL VOLTAGES (76 Cells)

April 4, $2003 \sim \mathrm{CY} \#$ 13,632

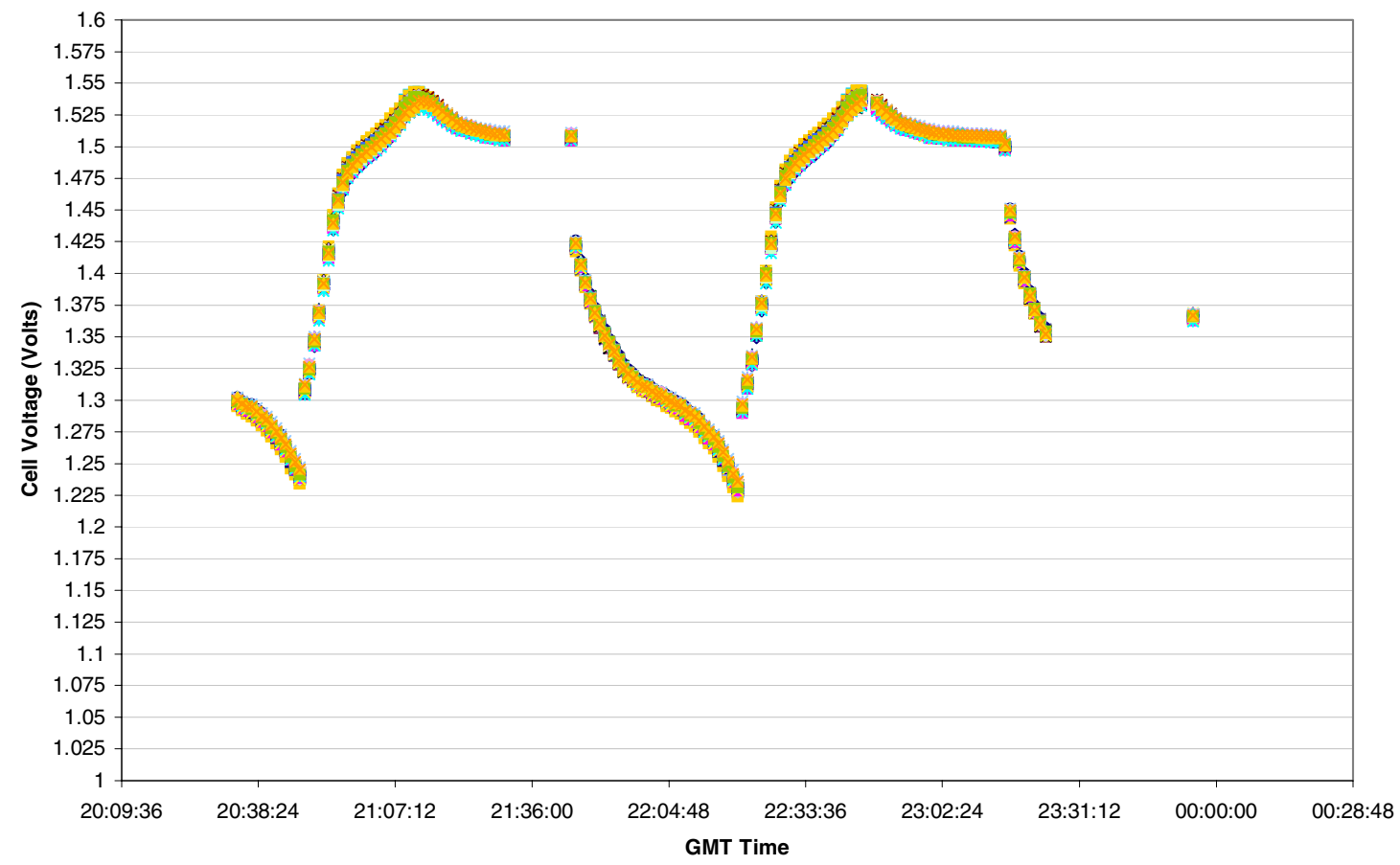

FIGURE 11. BATTERY 2B2 CELL VOLTAGES

BATTERY 4B2 CELL VOLTAGES (76 CELLS) April 12, $2003 \sim \mathrm{CY} \# 13,760$

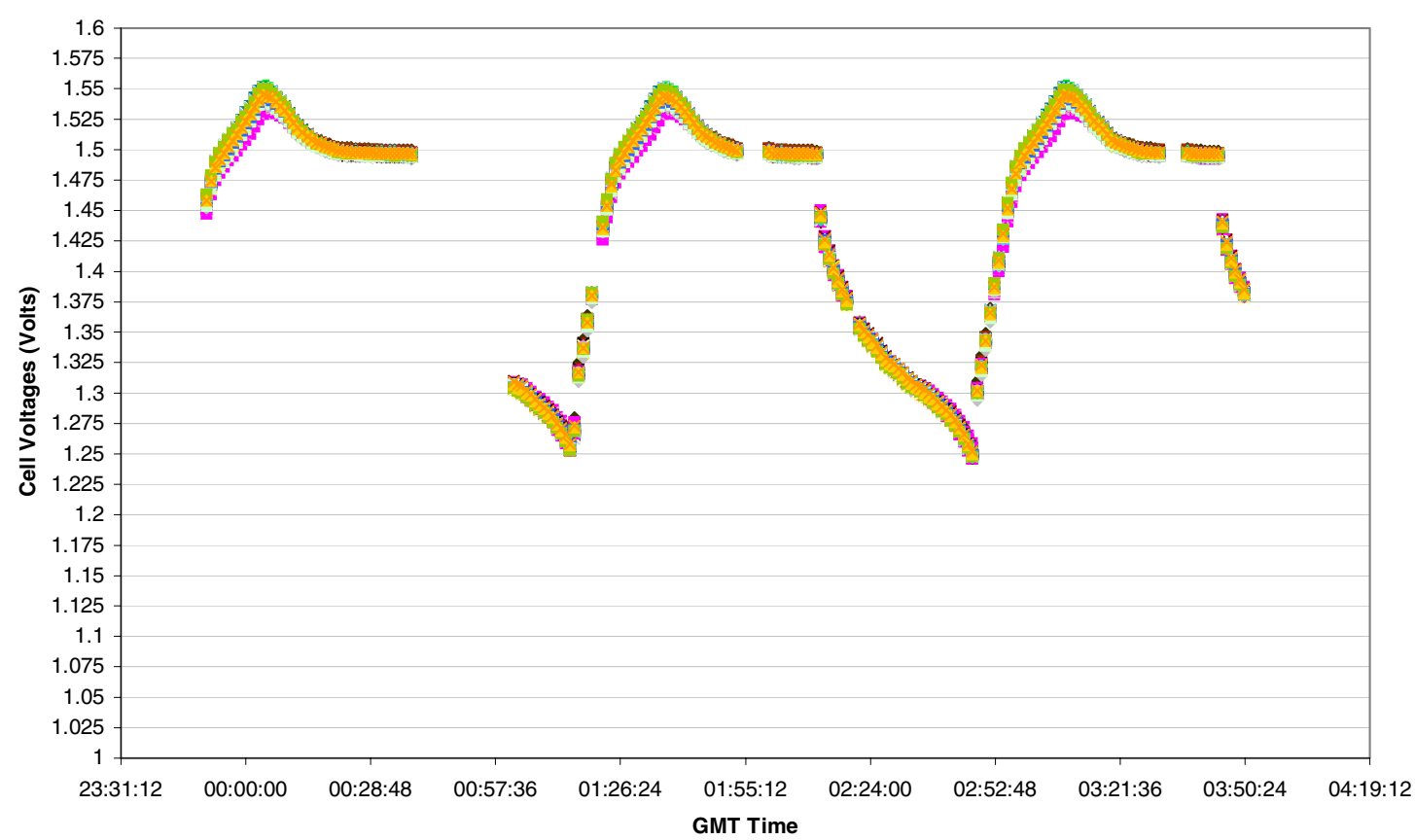

FIGURE 12. BATTERY 4B2 CELL VOLTAGES 


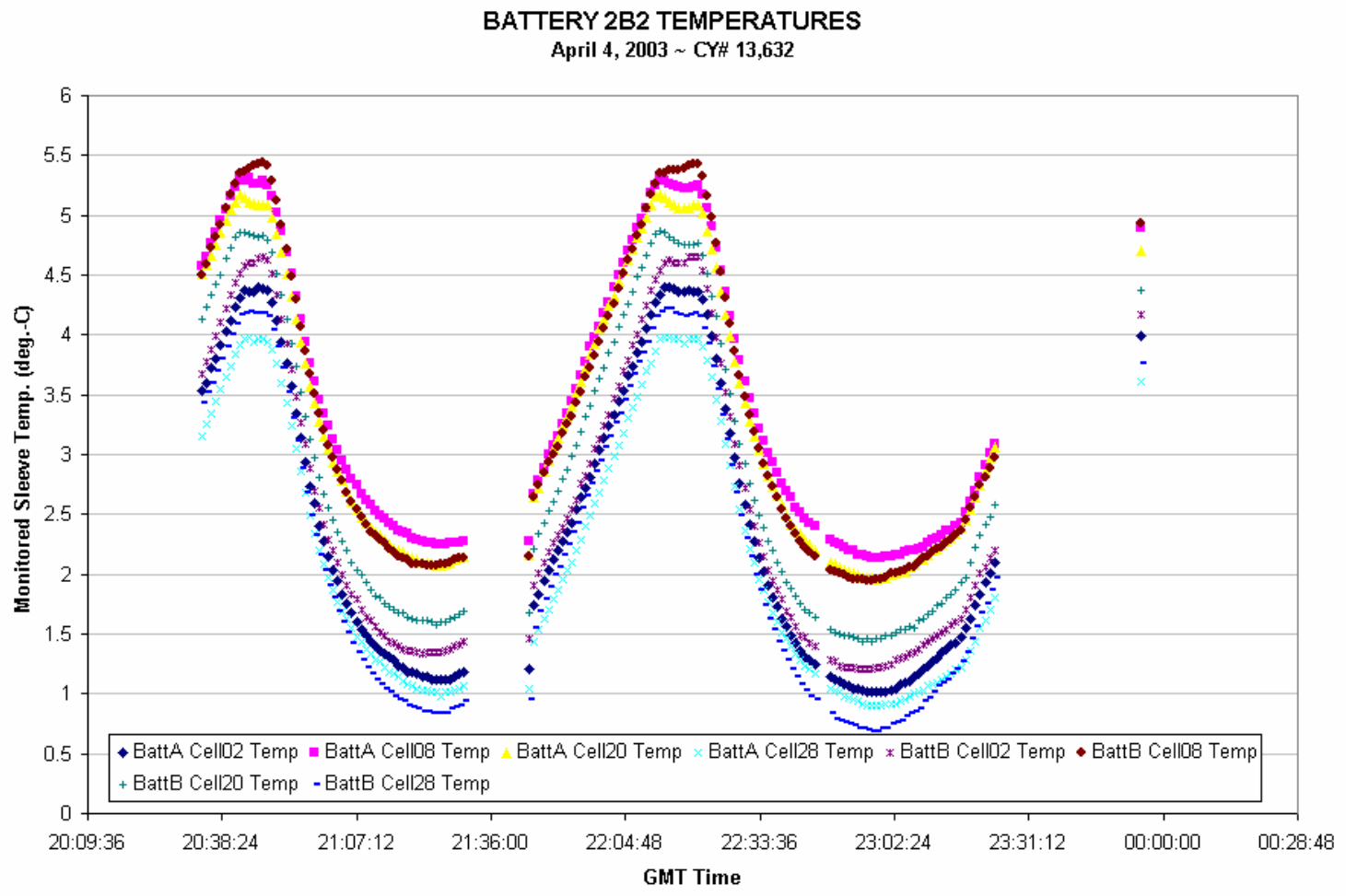

FIGURE 13. BATTERY 2B2 TEMPERATURES

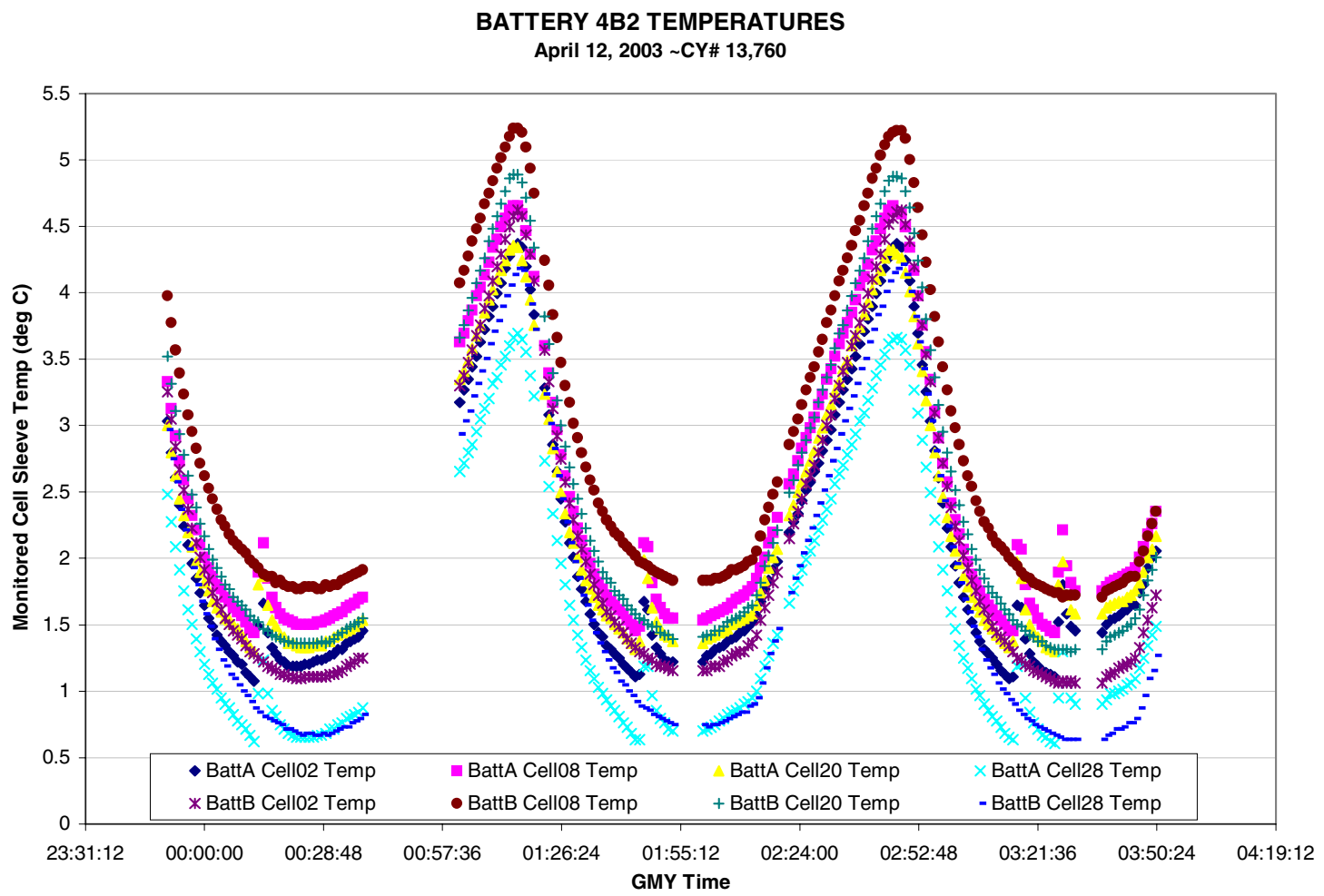

FIGURE 14. BATTERY 4B2 TEMPERATURES 
BATTERY 2B2 PRESSURE VS TIME

April 4, $2003 \sim \mathrm{CY} \# 13,632$

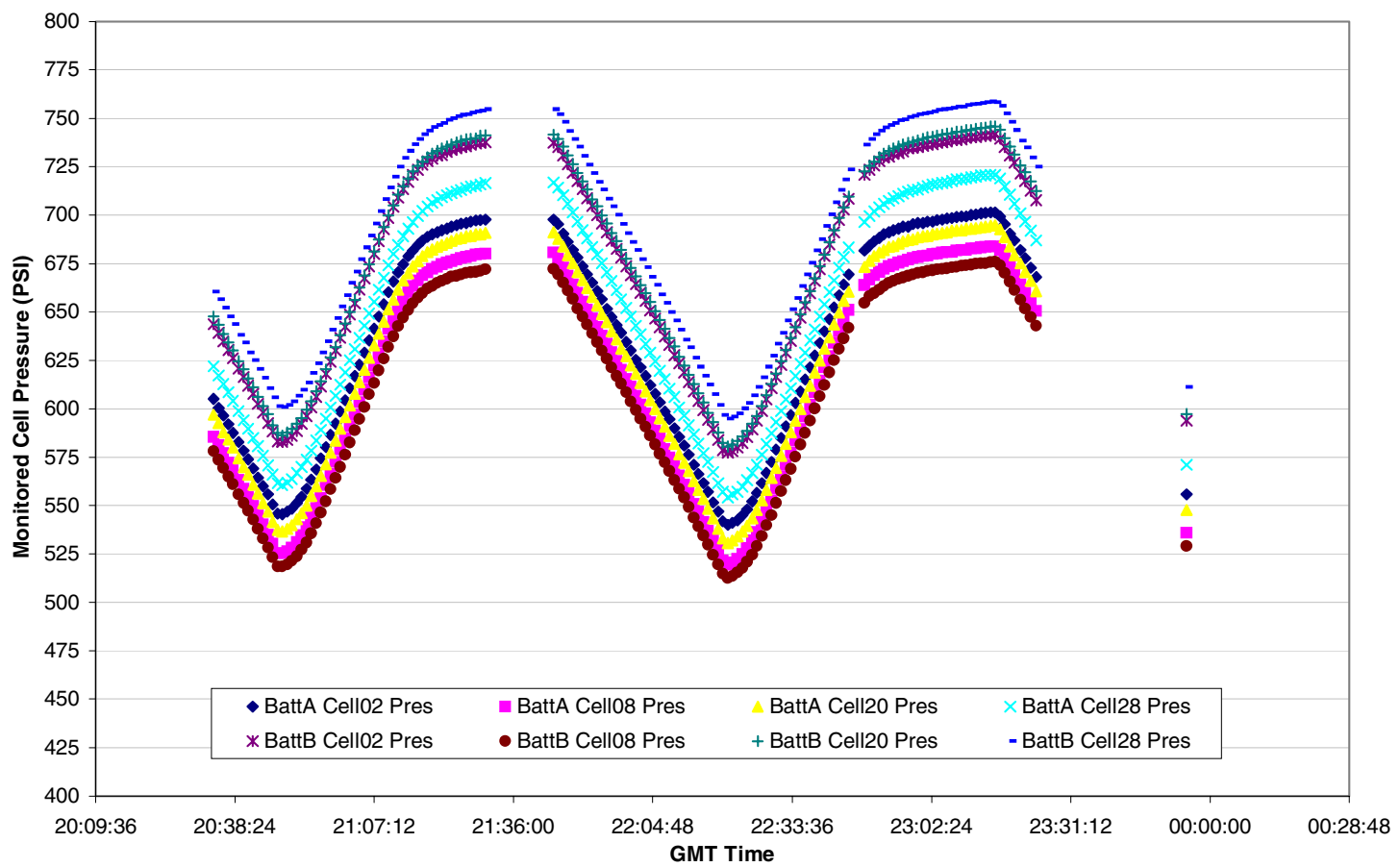

FIGURE 15. BATTERY 2B2 PRESSURES

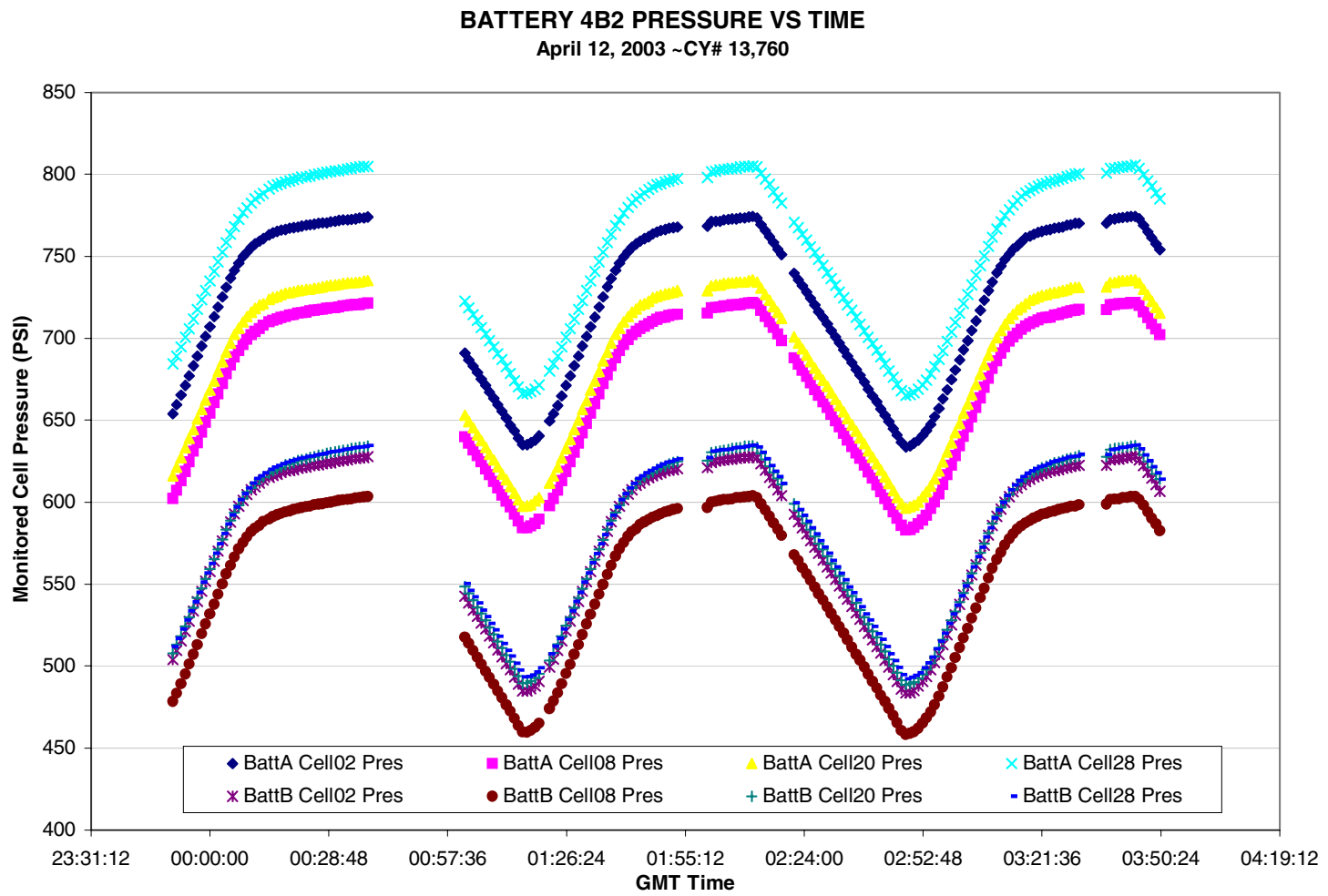

FIGURE 16. BATTERY 4B2 PRESSURES 


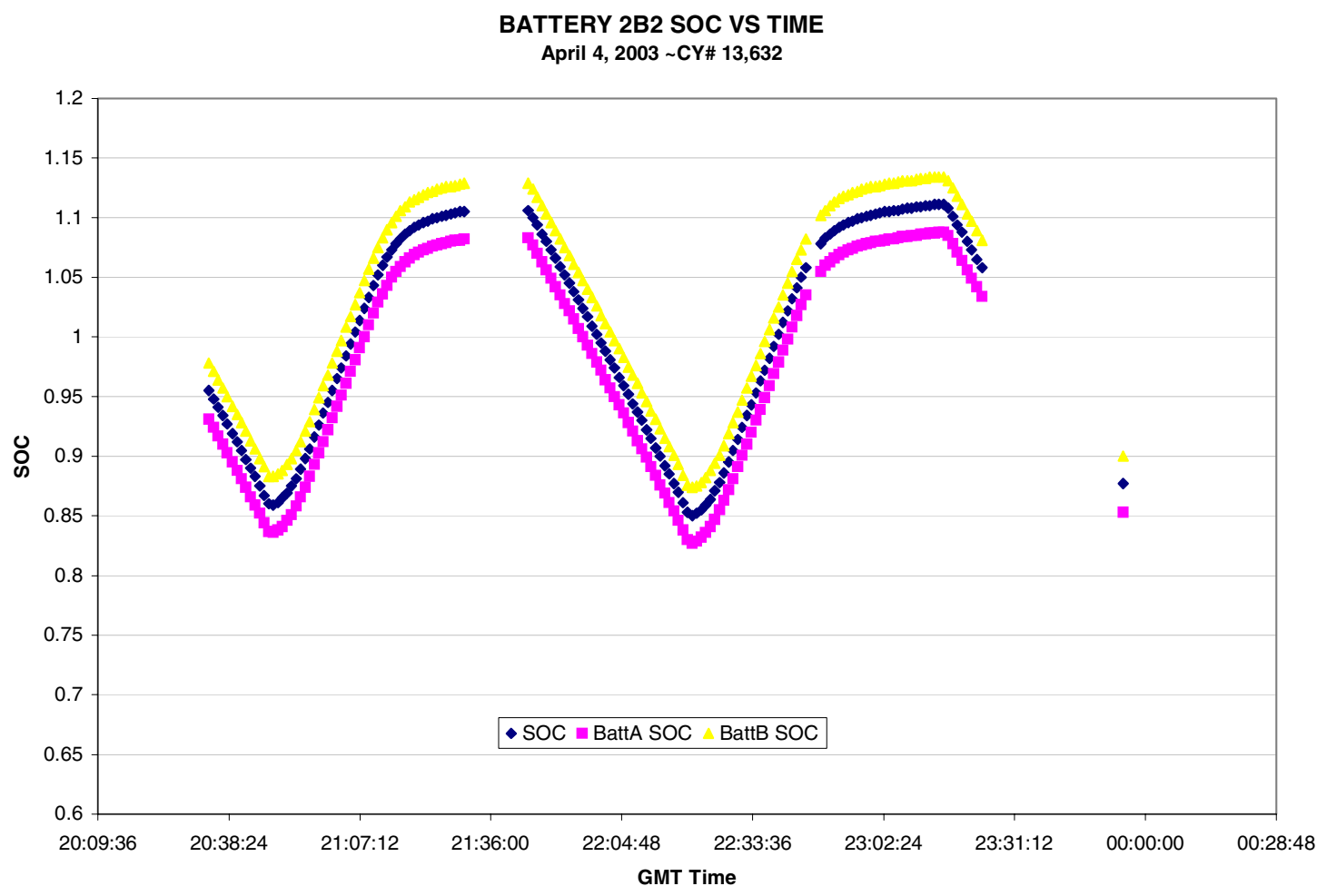

FIGURE 17. BATTERY 2B2 SOC

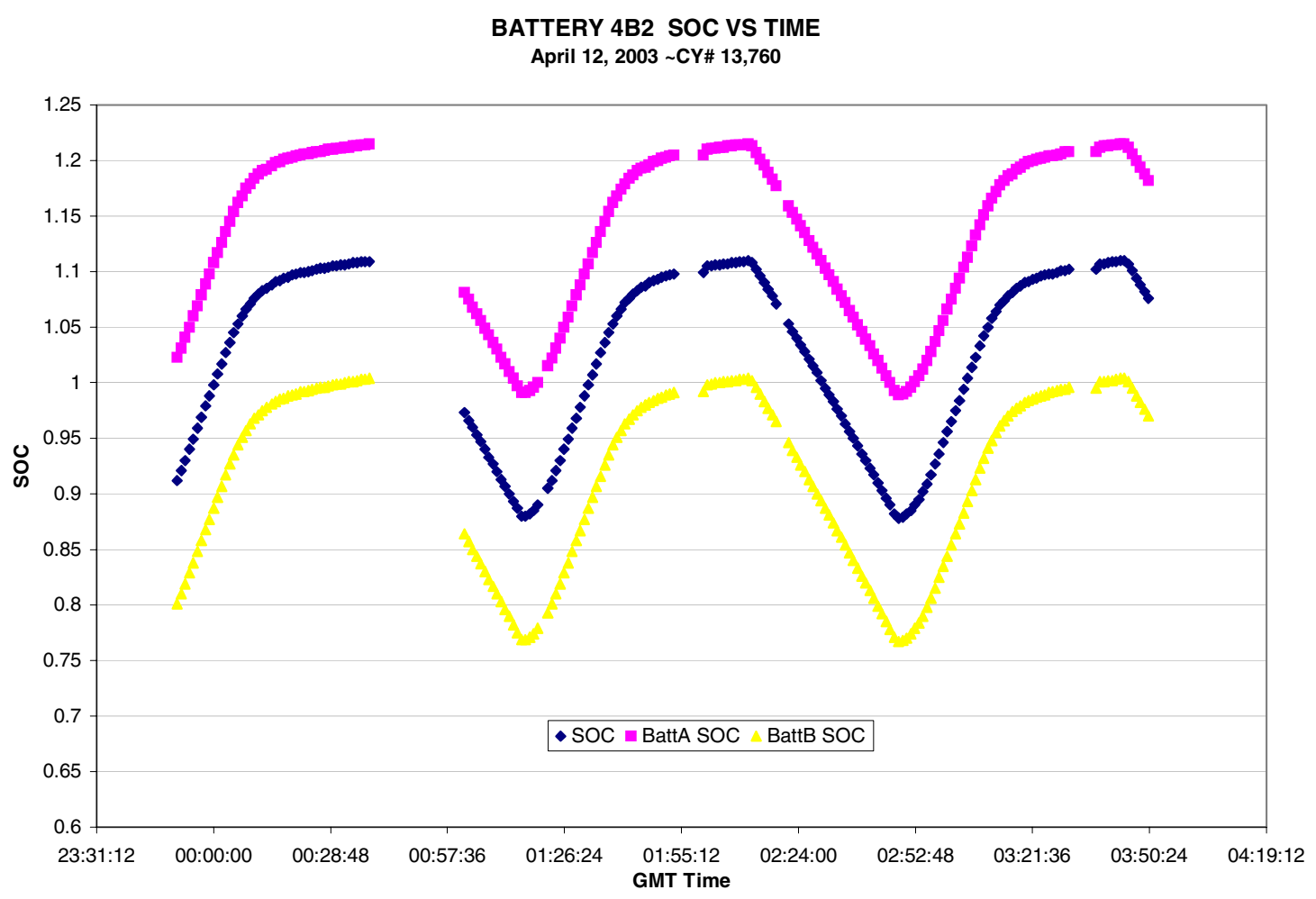

FIGURE 18. BATTERY 4B2 SOC 
Public reporting burden for this collection of information is estimated to average 1 hour per response, including the time for reviewing instructions, searching existing data sources, gathering and maintaining the data needed, and completing and reviewing the collection of information. Send comments regarding this burden estimate or any other aspect of this collection of information, including suggestions for reducing this burden, to Washington Headquarters Services, Directorate for Information Operations and Reports, 1215 Jefferson Davis Highway, Suite 1204, Arlington, VA 22202-4302, and to the Office of Management and Budget, Paperwork Reduction Project (0704-0188), Washington, DC 20503.

\begin{tabular}{|l|l|l}
\hline 1. AGENCY USE ONLY (Leave blank) & $\begin{array}{c}\text { 2. REPORT DATE } \\
\text { August } 2003\end{array}$ & $\begin{array}{r}\text { 3. REPORT TYPE AND DATES COVERED } \\
\text { Technical Memorandum }\end{array}$ \\
\hline
\end{tabular}

\section{TITLE AND SUBTITLE}

Update on International Space Station Nickel-Hydrogen Battery

On-Orbit Performance

\section{AUTHOR(S)}

Fred Cohen and Penni Dalton

\section{FUNDING NUMBERS}

WBS-22-335-14-03

\section{PERFORMING ORGANIZATION NAME(S) AND ADDRESS(ES)}

National Aeronautics and Space Administration

John H. Glenn Research Center at Lewis Field

Cleveland, Ohio 44135-3191
8. PERFORMING ORGANIZATION REPORT NUMBER

E-14108

\section{SPONSORING/MONITORING AGENCY NAME(S) AND ADDRESS(ES)}

National Aeronautics and Space Administration

Washington, DC 20546-0001
10. SPONSORING/MONITORING AGENCY REPORT NUMBER

NASA TM-2003-212542

AIAA-2003-6065

\section{SUPPLEMENTARY NOTES}

Prepared for the First International Energy Conversion Engineering Conference cosponsored by the American Institute of Aeronautics and Astronautics (AIAA), the American Society of Mechanical Engineers (ASME), and the Institute of Electrical and Electronics Engineers (IEEE), Portsmouth, Virginia, August 17-21, 2003. Fred Cohen, The Boeing Company, Canoga Park, California 91309; Penni Dalton, NASA Glenn Research Center. Responsible person, Penni Dalton, organization code 6910, 216-433-5223.

12a. DISTRIBUTION/AVAILABILITY STATEMENT 12b. DISTRIBUTION CODE

Unclassified - Unlimited

Subject Category: 20

Distribution: Nonstandard

Available electronically at http://gltrs.grc.nasa.gov

This publication is available from the NASA Center for AeroSpace Information, 301-621-0390.

13. ABSTRACT (Maximum 200 words)

International Space Station (ISS) Electric Power System (EPS) utilizes Nickel-Hydrogen $\left(\mathrm{Ni}_{2} \mathrm{H}_{2}\right)$ batteries as part of its power system to store electrical energy. The batteries are charged during insolation and discharged during eclipse. The batteries are designed to operate at a 35 percent depth of discharge (DOD) maximum during normal operation. Thirtyeight individual pressure vessel (IPV) $\mathrm{Ni}-\mathrm{H}_{2}$ battery cells are series-connected and packaged in an Orbital Replacement Unit (ORU). Two ORUs are series-connected utilizing a total of 76 cells, to form one battery. The ISS is the first application for low earth orbit (LEO) cycling of this quantity of series-connected cells. The P6 (Port) Integrated Equipment Assembly (IEA) containing the initial ISS high-power components was successfully launched on November 30, 2000. The IEA contains 12 Battery Subassembly ORUs (6 batteries) that provide station power during eclipse periods. This paper will discuss the battery performance data after two and a half years of cycling.

\section{SUBJECT TERMS}

Space station power; Batteries; Nickel hydrogen batteries

\begin{tabular}{|c|c|}
\hline $\begin{array}{c}\text { 17. SECURITY CLASSIFICATION } \\
\text { OF REPORT }\end{array}$ & $\begin{array}{c}\text { 18. SECURITY CLASSIFICATION } \\
\text { OF THIS PAGE } \\
\text { Unclassified }\end{array}$ \\
Unclassified
\end{tabular}

19. SECURITY CLASSIFICATION OF ABSTRACT

Unclassified 